\title{
Research on Development of Cultural Industry in Macau from LiYue ideology in the Analects of Confucius: Cultural Exchange between China and the West
}

\author{
Wu Haotian ${ }^{1}$, Liu Xiaoting ${ }^{2}$ \\ 1. Faculty of Urban management and studies, City University of Macau, Macau, 999078 \\ 2. FHSS, City University of Macau, Macau, 999078
}

\begin{abstract}
The Analects of Confucius records the deeds of Confucius and his disciples in the form of quotations. It is also a cultural classic, respected as the most valuable book in Chinese culture and classics. Featured with high added value and rapid growth, the cultural industry is an emerging industry oriented by creativity. Taking the cultural industry in Macau as the research object, this paper combs the theories on cultural industry development from the perspective of the cultural exchange between China and the Western, and further discusses the LiYue ideology of The Analects towards the cultural industry development in Macau.
\end{abstract}

Keywords-Macau; Analects of Confucius; LiYue; cultural industry

\section{INTRODUCTION}

The Analects, a Confucian classic passing down in China and also a classic on Chinese traditional culture, records the words and deeds of Confucius and his disciples in dialogues, and is respected as the most valuable books in Chinese culture and classics. There was a saying in ancient times that one could govern a country with half of The Analects, which reveals the huge role that The Analects played in the social and political life in ancient times. In addition to the idea of "benevolence", the rite and music ideology is also the core of it. I believe there are three major points in the rite and music ideology in The Analects: firstly, which includes, firstly the harmonious human relations; secondly, the innovation of the rite and music culture of the deceased emperor; thirdly, Confucius placement of the root of traditional rite and music culture into the life activities of that "the benevolent loves others". We are aware that featured by high added value, rapid growth and so on, cultural and creative industries are creativity-oriented emerging industries. Therefore, what kind of enlightenment can the idea of rite and music bring towards the boosting cultural and creative industries in Macau?

Wu Haotian (1993 - ), Doctoral candidate in urban planning and design, City University of Macau, Research direction: urban regeneration, creative city, cultural industry.

Liu Xiaoting (1994- ), Master of cultural industry management, City University of Macau, research direction: cultural change.

\section{THEORY REVIEW}

It is generally believed that, culture refers to the total of material wealth and spiritual wealth created during the development of human social history [1]. Cultural industry is a concept full of vitality. In 1926, Walter Benjamin published the article The Art in the Age of Mechanical Reproduction, in which he came up with the idea that, in terms of phonograph, film and radio, reproduction killed the aura in culture and art, making art works no longer a one-off existence, now shared by the majority. Benjamin believed that this was the revolution and liberation of culture, bringing new and vast space to the proletariat culture. Theodor Adorno and Max Horkheimer, however, held opposite attitudes towards this article. It is universally believed that the phrase "cultural industry" was first used by the German Jewish philosopher, Theodor Adorno, and Max Horkheimer in their co-written book Dialectic of Enlightenment, in which the phrase "cultural industry" was taken as part of the title of a chapter in the content. The book was written when they were refugees in the US, in which they believed that "cultural industry" was the development of technology governance and instrumental rationality of capitalism. The severely negative and critical attitudes they held towards the cultural industry were later widely applied to the criticism against the alienation of modern cultural life towards human beings. Whereas it is believed in this paper that the introduction of the concept of cultural industry shouldn't start from Theodor Adorno and Max Horkheimer only, instead, it should be traced back to the thoughts of Marx in the middle of the 20th century. In fact, Marx advanced his opinion towards "cultural industry" in a critical context quite early, which influenced the Lukacs, Gramsci and Frankfurt schools, Birmingham School and Levi's doctrine in western Marxism schools deeply. He mentioned in Economic and Philosophical Manuscripts of 1844 that, "people living in particular ranges", can treat "the ordinary and material industry" as the "reality of the essential power of human and part of human activities", as "ubiquity" and "part of the ubiquitous movement". Likewise, people can in turn "treat this ubiquity and ubiquitous movement as a special part of industry". Here, "ubiquity" and "ubiquitous movement" with "histories of abstract and universal nature" 
refer to "politics, art and characters, etc.", in which the ideology of "industrialized culture" or "cultural industry" is contained. It is worth paying special attention that it is on the premise of the discussion of "the alienation range" of capitalism that Marx said that "art and literature" can be viewed as "a special part of industry". In the meantime, he also pointed out clearly that: "activities of all people are merely labor, that is, industry, the activities of self-alienation". This is the first time that human's "cultural" behavior is connected with "industry production", that material production is "unified" with spiritual production activities, becoming one of the origins of "cultural industry".[ ][1]When Marx talked about "productive labor" and "non-productive labor", he mentioned the labor characteristic of "cultural industry". A writer's "labor is the creation of certain thing, in which case his labor isn't thus the productive labor in economic sense, just like that the labor of madman with hallucination isn't productive labor. Only when the labor produces an opposite side of itself can it be called productive labor". [2]

And the representatives in the theory of "cultural hegemony" advocated by Gramsci, Frankfurt school, Levi's doctrine and Birmingham school after Marx were all deeply influenced by his ideological tradition. Study achievements of Frankfurt school are shown in a series of representative works, like Adorno's On Pop Music and Cultural Industry Reconsidered, Art and Mass Culture and Philosophy as Cultural Criticism written by Horkheimer, Eros and Civilization and One-dimensional Man written by Marcuse, as well as Science and Technology is Ideology written by Habermas.

Levi's doctrine, emerging at the same time with Frankfurt school, also proposed their criticism theory against cultural industry, in which they focused on mass culture and commercial forms. Through the research of the social and economic structures in Britain in the 17th century, F. R. Levis believed that the rise of industrial revolution brought the development of civilian culture, dividing the native British cultural tradition into the elite culture of the minority and the mass culture, and thus caused the antagonism of the elite culture and mass culture. Denise Thompson discussed the advertisement in the commercial culture of cultural development in his book Culture and Environment, in which he held the opinion that, polluted by business profits, shared cultural was ill, and advertisement is one of the major cause of the disease.

In the 1950s, there was a debate of mass culture in which Macdonald, David Mourning White, Ernest Van den Haag and Edward Hills were representatives. In 1964, BirminghalT, also called "culture research", was established in Britain, represented by Raymond Williams, Stuart Hall, Richard Hoart and E. P. Thompson. Raymond Williams believes that: "culture is the panorama of life of a particular group of people or social groups". He combined the research method of political economics and radical media sociology to establish the Marxism research theory in the era of "professional companies" of cultural production. Raymond Williams proposed that: "protection system of innovation gives its places to the symbol innovation organization in the market, based on which the cultural industry starts to appear." Richard
Hoart pointed out that the mass culture in the 1969s was thoroughly a "commercial culture" in which the morality of the working class could reform the products of cultural industry and practice [3]. His opinions revealed the thoughts of Kantianism and he understood the key of the problem as the lack and establishment of morality. Stuart Hall held the opinion that cultural innovation was more and more important. Through cultural innovation, "the field composed of activity, system and time, which we call culture, expands aggressively beyond our cognition". When talking about "cultural imperialism", he criticized that: "there are many counterbalanced trends which protect the world from becoming a homogenized cultural space."

John Fiske's theory introduced the research of mass culture into the observation of detailed media clearly, and he wrote the books like Understanding of Mass Culture, Interpretation of Mass Culture, etc., in which the media like television replaced the previous questions and became the focus of attention. The publication of McLuhan's book, Understanding of Media, pushed the research of cultural problems from the perspective of media to the climax. He analyzed the formulation and development of modern media systematically, demonstrated the social functions of media through the explanation of the structure and form of media themselves, and predicted the future of media, society and human being bravely.

In the 1970s, the development of feminism provided a new breakthrough for the cultural industry research from the perspective of gender location and political analysis. Matterlart believed that it was in the cultural industry in the modern capitalism that basic gender discrimination was presented: "although there is huge potential value in women's time, it is definitely discriminated in our society. People are used to understand and spend it as the repeated and monotonous time in ordinary life."'[4]

Systematic philosophical discourses of "poststructuralism" and "post-modernism" terminate the cultural theory study in the middle and late 20th century. Michel Foucault, Jacques Derrida, Jacques Lacan and Edward W. Said subjected culture in the post-structuralism philosophy. Michel Foucault came up with the idea that the "discourse", "knowledge", "governance" and "power" in post industrial society affirmed that knowledge was developed from power, and again transformed into a weapon of power. Therefore, power has the function of production, that is power creates reality. In media era, the relationship between the media power and knowledge is worth researching. Edward W. Said came up with the idea that the concept of "the East" is a characterization of "eastern knowledge" and the relationship system of "power-knowledge" created by the western discourse in order to define itself effectively, which reveals the essence of the antagonism between the West and the East. Lyotard proposed the concepts of meta-narratives and grand narrative, and pointed out that the era of "grand narrative" had ended and that the post-modern western society boycotted meta-narratives, represented by the crisis of the status of knowledge. He revealed that, the only criterion of the value in mass culture is money, and therefore he questioned the meaning and purpose of contemporary pop culture. Jurgen 
Habermas mentioned in his works Structure Transformation in the Common Field in Common Field and Theory of Communicative Action the theories of "interaction" and "inter-subjectivity of consensus", inheriting the tradition of continental philosophy and extending the questions of truth, communication, etc. on which the philosophers like Martin Heidegger laid emphasis into the fields of media and technology [5].

Representative of post-modernism, Jean Baudrillard describes an abstract, non-material, simulative and surreal post-modern world. He believes that all the new years of western culture are based on "appearance". Using McLuhan concept of "internal explosion", he explains that the development of media causes the occurrence of social "hyperrealism" and the aesthetic "internal explosion". He also believes that, in the post modern world, the boundary between the simulation and entity has exploded internally, and therefore, the exact experience and basis of reality disappear, too. Fredric Jameson, scholar of post-modern theory in the western Marxism believes that: "the modernism has passed, and the post-modernism which serves as the presentation of the logic of late capitalistic culture has arrived, giving rise to an essential breakage in the social and cultural organizations in modern society. We have entered the post-modernism.'[6]

The geographer David Harvey points out that: in a new era where the culture changes easily beyond prediction, "cultural industry is quite important towards control symbol system"; "culture changes more and more easily, and becomes ephemeral". He explains these as the results of the compression of time and space, which are caused by the need of capitalists to accumulate profits [7].

\section{MACAU PERSPECTIVE}

In The Analects, there is a saying that "sharp tools make good work", which means that: if a craftsman wants to perform his job well, he has to make the tools sharp first. This reflects the rite and music ideology in The Analects that "focuses on the basis and the essence". From this perspective, it is also necessary for Macau to devote itself into "sharpening the tools" during the cultural industry development. Macau SAR Government established the cultural industry committee in May 2010 and cultural industry funds at the end of 2013. It has also formulated policies which support the development of cultural industry and planned to build up a series of cultural innovation industry parks. You can see SAR government's attention and support. However, there are some problems during "sharpening the tools": for instance, innovation level of the cultural innovation products waits to be improved; cultural innovation industry doesn't have clear features; the scale is small and dispersive; the connection between each other isn't close enough, etc. These problems need to be solved with the cooperative efforts of all social aspects.

The master said: "Isn't it a pleasure to learn and repeat from time to time? Isn't it delightful to have friends coming from afar?" What he meant in this chapter is that: "isn't it a pleasure to learn and revise on time? Isn't it happy to welcome like-minded friends from a remote place?" this is also a chapter in The Analects, which seems to talk about study and how to treat your friends, but actually is about the rite and music ideology which "lays emphasis on the talent cultivation and innovation". Developing cultural innovation industry is to learn and study relevant knowledge about cultural innovation industry, cultivate related talents, offer a development platform for them to allow them apply what they have learnt and reach the highest level that "Isn't it a pleasure to learn and repeat from time to time?" It is necessary for Macau to strengthen the development and innovation of cultural industry theories, and combine other good theories, achievements and experience with Macau actual situation. In the meantime, it is also necessary to absorb "friends from afar" with "ambition, culture, ability and same goals", that is, to attract more talented people to Macau cultural innovation industry, and give those who want to do something the opportunity, offer those who are able to do something the stage, making itself another high land for cultural innovation talents and reaching the level that "isn't it a pleasure to have friends from afar?"

The saying that "in the actual practice of rite, harmony is important" in The Analects points out the rite and music ideology which "starts in rite and develop in music". It means that "rite" is used to maintain the social order, while "music" is in pursuit of harmony and happiness. "Harmony" is one of the essence in Chinese culture. In President Xi's explanation of the excellent traditional Chinese culture, he mentions that we should "pursue the harmony and the great harmony". During the process of cultural innovation industry development, Macau should also pursue the coordinate industry innovation with neighboring regions. There isn't the superior or the inferior in the coordination, instead, there is the great harmony of "coordinating together and sharing the success together". From the perspective of market subjects, cultural products can merge with technology, can be transplanted to tourism, and can also be connected to finance, manufacturing and agriculture. Modern cultural products are all the products of coordinative work. Macau can coordinate with Guangdong, Hong Kong and so on in terms of innovation in cultural industry according to its own actual conditions, make up each other's drawbacks, solve the actual problems occurring in the development of cultural innovation industry, create a coordinative path for cultural innovation industry in Macau and thus realize the double goals of "harmony" and "cooperation".

The Master said, "The three hundred poems from the Book of Poetry could be summed up in a single phrase: "They never swerve from the path." It means that: three hundred poems from the Book of Poetry can be concluded in one sentence, that is "they have pure thoughts". This is the idea of rite and music, guiding the "shaping of gentleman's personality" and moral cultivation. The stance, direction, guidance and shaping of culture are mentioned in it. In the economic sense, cultural product is a public product with significant guiding function, and therefore special attention should be paid to its "pure thoughts". Macau should also pay attention to the guidance and purity of cultural innovation products in the production, drawing them closer to the noble culture voluntarily, and give more support to the cultural products people like, resist the vulgar cultural products which do damage to the image of 
Macau and achieve the pure thoughts of cultural innovation products.

\section{CONCLUSION}

The well-known historian, Qian Mu, once said that: The Analects applies to every aspect of life. I have a very shallow and limited understanding of the idea of rite and music in The Analects, as well as of the cultural innovation in Macau, not to mention whether my opinions are the same things as those of specialists. Yet I believe that, really great thoughts won't merely apply to one time, one place or one person. They always have a universal meaning, and include everyone into them with their tolerance and flow; they always allow everyone to extend the values which reach the same goal from different means. This is perhaps the connotation of the saying "the Way doesn't repel anyone". This is the cultural innovation in Macau, and this is the real meaning which we can borrow from the rite and music ideology in The Analects.

\section{REFERENCES}

[1] Marx and Engels in the Central Committee of the Communist Party of China: Karl Marx and Frederick Engels[M], vol.42, Beijing: People's Publishing House. 2006. P127-128.

[2] Marx and Engels in the Central Committee of the Communist Party of China: Karl Marx and Frederick Engels[M], vol.42 (I), Beijing: People's Publishing House. 2006. P264.

[3] Lu Daofu, Hu Jiangfeng. Academic tradition of the Cultural Research of BirminghalTl School, Academic Forum, 2006, vol.3
[4] Michel Materat: Female and Cultural Industry, The Way of Media Research, edited by Boyd Barrett, Beijing: Xinhua Publishing House, 2004, P516.

[5] Song Meng: Development Thread of the Cultural Industry Theory in the 20th Century, Theory and Creation, 2006, vol.4

[6] Zhan Mingxin, Zhang Xudong et al. Cultural Logic of Capitalism in the Later Stage: Zhan Mingxin's critical theory of literary selection, Shanghai: Joint Publishing, 1997, P36-85.

[7] David Harvey: The Condition of Post-Modernism, Shanghai, Commercial Press, 2013, P57-113.

[8] David Hesmondhalgh. Cultural Industry [M]. China Renmin University Press, 2016. (In Chinese)

[9] Confucius. The Translation of the Analects, the 2nd edition [M]. Zhong Hua Book Company, 1980.(In Chinese)

[10] Zeng Changqiu. Thoughts of Marx and Engels on Cultural Industry [J]. Journal of Central South University (social science), 2010, 16(2):69-72. (In Chinese)

[11] Li Chengshi. Marx's Thoughts of Cultural Industry and Its Contemporary Meaning [J]. Journal of the United University of Hebei (social science), 2013, 13(6):9-12. (In Chinese)

[12] Cai Xiangjun. On the Influence of Traditional Chinese Culture on Cultural Industry Thought $[\mathrm{J}]$. Monthly Literature of the Times, 2010(2):178-179. (In Chinese)

[13] Zhang Han. On the Research of "Cultural Industry" Involved in Marx's Works [J]. Research of Marxism, 2009(3):53-58. (In Chinese)

[14] Liu Fang. Marx's Cultural Product Thought and Development of Cultural Industry [J]. Dongyue Forum, 2014, 35(9):85-89. (In Chinese)

[15] Wang Jiyuan. Discussion of Marx's Cultural Thoughts on the Value Guidance of Contemporary Development of Cultural Industry [J], Shandong Social Science, 2013(11):120-124. (In Chinese) 